\title{
METHODS OF LARGE-SCALE SIGNALS TRANSFORMATION FOR DIAGNOSIS IN NEURAL NETWORK MODELS
}

Lymariev I. O. - Student of the Department of Software Tools, Zaporizhzhia National Technical University, Zaporizhzhia, Ukraine.

Subbotin S. A. - Dr. Sc., Professor, Head of the Department of Software Tools, Zaporizhzhia National Technical University, Zaporizhzhia, Ukraine.

Oliinyk A. A. - PhD, Associate Professor, Associate Professor of the Department of Software Tools, Zaporizhzhia National Technical University, Zaporizhzhia, Ukraine.

Drokin I. V. - Chief of the Research Department of General Constructor's Administration, "Motor Sich" JSC, Zaporizhzhia, Ukraine.

Context. The problem of dimensionality reduction of diagnosis signals for their use in neural network models is considered. The object of the study was the process of transformation of diagnosis input signals for their subsequent use in the synthesis of predictive models.

Objective. The goal of the work is the creation of the methods for the conversion of diagnosis signals as a result of the application of which new signals will be obtained, which in turn will be used in the construction of neural network predictive models and will significantly reduce the synthesis time of the model by reducing their dimension and the allocation of the necessary components that characterize the state of the individual elements of the object of diagnosis.

Method. The methods of reducing the dimension of the input signals of diagnosis and isolation of their components, which characterize the state of the individual elements of the object of diagnosis on the basis of expert knowledge about the process of diagnosis are proposed. The developed methods are based on the methods of digital signal processing. Based on the expert knowledge of the object and the process of diagnosis, the necessary signal conversion procedures and their parameters are selected. In accordance with the requirements for the desired accuracy and detail of the forecast, the optimal degree of averaging of the signal is selected, which directly affects the speed of constructing the predictive model. The proposed methods can be used in the transformation of diagnosis signals of various diagnostic processes where there is a need to build neural network predictive models based on high-dimensional signals. The developed methods were investigated for the conversion of diagnostic signals obtained on a complex object of technical diagnostics, namely, on the transmission of the helicopter. On the basis of the received signals, a neural network model was synthesized, the training of which requires much less computational resources, while the prediction accuracy remains optimal.

Results. The developed methods are implemented programmatically and investigated in solving the problem of predicting the future state of the helicopter transmission during the diagnosis process.

Conclusions. The experiments have confirmed the effectiveness of the developed methods and allow us to recommend them for use in practice in solving diagnostic problems. The conducted experiments have confirmed the proposed software operability and allow recommending it for use in practice for solving the problems of diagnosis and automatic classification on the features. The prospects for further research may include the search for the best parameters of the developed methods, optimization of their software implementations, as well as experimental study of the proposed methods on a large set of practical problems of diagnosing complex objects of different nature by their diagnostic signals.

KEYWORDS: signal processing, neural network, instance, feature, data dimensionality reduction.

\author{
ABBREVIATIONS \\ GRU is a gated recurrent unit; \\ HUMS is a Health and Usage Monitoring Systems; \\ LSTM is a long short-term memory; \\ $\mathrm{NN}$ is a neural network; \\ $\mathrm{RNN}$ is a reccurent neural network;
}

\section{NOMENCLATURE}

$C$ is a condenser capacity;

$\varepsilon$ is a ripple factor;

$F()$ is a neural network model structure;

$f()$ is a user criterion characterizing the argument qual-

ity relatively to the problem being solved;

$H$ is a sampling rate of the signal envelope;

$N$ is a number of time steps in signal;

$n$ is an order of the filter;

$R$ is a resistance of the resistor;

$\sigma$ is a sigmoid activation function;

$T_{n}(x)$ is a Chebyshev polynomial of the $n$-th order; $\tau$ is an averaging time of the signal;

tanh is a hyperbolic tangent activation function;

$\omega_{0}$ is a cutoff frequency;

$\omega(t)$ is a signal envelope;

$w$ is a set of controlled (adjusted) parameters of the neural network model;

$x_{j}^{s}$ is a value of $j$-th input feature $x_{j}$, characterizing the instance $x^{s}$;

$y^{s}$ is an output feature value associated with the instance $x^{s}$;

$y^{s^{*}}$ is a calculated output feature value for the $s$-th instance on the neural model output;

$x^{s}$ is $s$-th instance of a sample;

$x(t)$ is an input signal;

$x_{f}(t)$ is a signal received as a result of the recursive filtering stage;

$\psi(t)$ is a Hilbert transform of signal. 


\section{INTRODUCTION}

To automate decision making and forecasting in the tasks of technical and medical diagnostics, it is necessary to have a model of dependence of the solution on the descriptive features characterizing the recognized instance (observation of the state of the object or process at a certain point in time). As a rule, the modern diagnostic process is carried out over a period of time, during which observations are recorded and can be presented in the form of sets of diagnostic signals.

One of the most popular and powerful tools for constructing models based on diagnostic signals is artificial radial basis NN and RNN [1], which can learn by precedents, providing their generalization and knowledge extraction from data.

The object of study was the process of transformation of diagnosis input signals for their subsequent use in the synthesis of predictive models.

The process of neural model building is typically time-consuming and highly iterative. This is caused by that training time and accuracy of the $\mathrm{NN}$ model are essentially dependent on the dimensionality and quality of the used training sample. Therefore, to improve the speed of construction and quality of the neural model, it is necessary to reduce the dimension of the input signals of diagnosis, by isolating the necessary components from them and further averaging them, thereby ensuring the preservation of their basic properties.

The subject of study is the methods of reducing the dimension of the input signals of diagnosis and isolation of their components, which characterize the state of the individual elements of the object of diagnosis.

The known methods of reducing the training sample [2] aren't optimal for applying them to diagnostic signals with a high sampling rate due to the large requirements for time and computational resources and the complexity of their implementation in practice.

The purpose of the work is the conversion of diagnosis signals as a result of which new signals will be obtained, which in turn will be used in the construction of $\mathrm{NN}$ predictive models and will significantly reduce the synthesis time of the model by reducing their dimension and the allocation of the necessary components that characterize the state of the individual elements of the object of diagnosis.

\section{PROBLEM STATEMENT}

Consider the problem of diagnosing the helicopter transmission. Preventing machinery failure is an important component of the maintenance activities of most engineering systems. Helicopters are constantly exposed to periodic loads and vibrations that initiate and propagate the occurrence of damage in many components of the equipment. This is due to the design of the helicopter and the presence of complex mechanical systems, such as the inventive rotor, control rotor, main gearbox and other transmission elements. In most cases, the failure of these systems lead to catastrophic situations. (C) Lymariev I. O., Subbotin S. A., Oliinyk A. A., Drokin I. V., 2018 DOI 10.15588/1607-3274-2018-4-11
HUMS are used to monitor the technical condition of the helicopter [3]. These systems make possible to detect damage in the transmission components and predict their residual life.

In this paper, we set the task of long-term forecasting of the state of the helicopter transmission during the ground test. This type of test allows the use of significant computing power, which is important when working with a large number of signals, which are measured at a high sampling rate and for significant periods of time. However, with this type of test, it is necessary to build predictive models that will work correctly on long-term periods of time.

Formally, the problem of neuromodels synthesis can be presented in this form.

Suppose given the original sample as a set of precedents (instances) $\left\langle x_{t}, y_{t}\right\rangle$ is a set of $S$ precedents characterizing dependence $y_{t}\left(x_{t}\right)$, at the moment $t, t=1,2$, $\ldots, T$, where $x_{t}=\left\{x_{t}^{s}\right\}, y=\left\{y_{t}^{s}\right\}, s=1,2, \ldots, S$, characterized by the set of $N$ input features $\left\{x_{j}^{t}\right\}, j=1,2, \ldots, N$, where $j$ is a number of feature, and output feature $y$. Each $s$-th precedent can be noted as $\left\langle x_{t}^{s}, y_{t}^{s}\right\rangle$, where $x_{t}^{s}=\left\{x_{t j}^{s}\right\}$.

Then the problem of model synthesis of dependence $y_{t}\left(x_{t}\right)$ will be considered in search of such structure $F()$ and adjusting such values of parameters $w$ of a model which will satisfy the model quality criterion $f\left(F(), w,<x_{t}\right.$, $\left.y_{t}>\right) \rightarrow o p t$, where opt-is a symbol of optimum.

In case when the original sample has a big dimensionality before model building we need to decide a problem of less size subsample selection from the original sample (given: $X=<x_{t}, y_{t}>, t=1,2, \ldots, T$, needed: $X^{\prime}=<x_{p}^{\prime}, y_{p}^{\prime}>$,

$p=1,2, \ldots, P$, where $\left.P<<T, f\left(<x_{p}^{\prime}, y_{p}^{\prime}>,<x_{b} y_{t}\right\rangle\right) \rightarrow$ opt $)$.

To build the model in the problem we used the data of vibration diagnostics of the helicopter transmission containing fifteen piezoelectric sensors to monitor the level of vibration mounted on the transmission components, such as: rotor shaft cover, coupling flange of the upper and lower part of the gearbox, drive flange of main rotor, intermediate gearbox and tail gearbox. At the mounting point, there are 3 sensors that allow monitoring vibration parameters in mutually perpendicular planes.

\section{REVIEW OF THE LITERATURE}

The problem of long-term forecasting of the state of the helicopter transmission includes the solution of a complex of subtasks of forecasting the state of individual elements of the transmission [4]. Usually this problem is solved by predicting the next $N$ values of a certain diagnostic signal [5].

However, this approach has shortcomings that make it difficult to put into practice. First, the input signal has low informativeness regarding the state of a particular transmission element. Secondly, the condition of the transmission element is usually characterized not by one, but by several different diagnostic signals. Third, the input signals have a large sampling rate.

At the same time, there is a need to build predictive models based on big data to ensure satisfactory prediction accuracy. These limitations make the process of synthesis 
and training of models based on computational intelligence such time-consuming and computational resources.

Signal transformation is an important problem in the construction of analytical and predictive models that work based on computational intelligence. The development of such models is associated with the need to process big data $[1-2,6]$. Typically, the input selection data which represent the signals which describe the investigated processes may contain redundant and uninformative information [7-8]. The use of such information in the synthesis of models leads to an increase in their complexity, redundancy, reduction of generalizing capabilities and can make the synthesized model unusable due to the need for large computational resources.

Usually, to solve this problem, the data is preprocessed to exclude from the training sample redundant features and instances. Most of the known methods use a greedy or stochastic search strategy [9]. Both of these strategies aren't optimal for working with time sequences that are represented by signals with a high sampling rate due to the large time and computational resources and the complexity of their implementation in practice.

One of the most effective tools for data analysis is signal processing [10]. It has a large number of means to allocate the necessary components of the signal, its normalization and averaging.

\section{MATERIALS AND METHODS}

To solve these problems, two methods for converting input signals based on signal processing methods have been developed and can be used to monitor and predict the state of a certain transmission element when specifying the signal processing parameters.

The method of signal transformation to obtain values for the vibration overload parameter is proposed to be used to obtain an assessment of the state of the transmission element with the vibration overload parameter.

Initialization stage. Set input signal $x(t)$.

Recursive filtering stage. To apply to the input signal $x(t)$ type I Chebyshev filter to select from it the necessary frequency band, which characterizes the state of the transmission element. According to [10] the amplitude frequency characteristic of the type I Chebyshev filter is defined as (2):

$$
K(\omega)=\frac{1}{\sqrt{1+\varepsilon^{2} T_{n}^{2}\left(\omega / \omega_{0}\right)}} .
$$

Selection of the signal envelope stage. Select the signal envelope to obtain the absolute value of the signal. For this, according to [11], the signal received as a result of the previous stage can be represented as an analytical signal with addition to the real signal $x_{f}(t)$ of its Hilbert transformation as imaginary part (2):

$$
\psi(t)=x_{f}(t)+j \hat{x}_{f}(t)
$$

(C) Lymariev I. O., Subbotin S. A., Oliinyk A. A., Drokin I. V., 2018 DOI 10.15588/1607-3274-2018-4-11 from here signal envelope is defined as (3):

$$
\omega(t)=|\psi(t)|=\sqrt{x_{f}^{2}(t)+\hat{x}_{f}^{2}(t)} .
$$

Selection of the envelope signal is carried out using a peak detector [12], which is used to allocate the maximum and minimum values of the signal envelope.

Signal averaging stage. Get the average value of the signal amplitude over $\tau$ seconds by the formula (4):

$$
x^{\prime}(p)=\frac{\sum_{i=1}^{H \tau} \omega(i)}{H \tau}, p=1,2, \ldots, P .
$$

The method of signal transformation to obtain values for the vibration speed parameter is proposed to be used to obtain an assessment of the state of the transmission element with the vibration speed parameter.

Initialization stage. Set input signal $x(t)$. Recursive filtering stage. To apply to the input signal $x(t)$ type I Chebyshev filter to select from it the necessary frequency band, which characterizes the state of the transmission element.

Signal integration stage. To integrate the signal by the method of RC-circuit [13] with the number of averaging points $N$ to change the parameter to the vibration speed parameter. An RC circuit is an electrical circuit consisting of a resistor $R$ and a capacitor $C$. Integration is performed by the formula:

$$
x_{\mathrm{int}}(t) \approx \frac{1}{R C} \int_{0}^{t} x_{f}(t) d t, x_{\mathrm{int}}(t)<<x_{f}(t) .
$$

Selection of the signal envelope stage. Select the signal envelope (2)-(3) to obtain the absolute value of the signal. Selection of the envelope signal is carried out using a peak detector which is used to allocate the maximum and minimum values of the signal envelope.

Signal averaging stage. Get the average value of the signal amplitude over $\tau$ seconds by the formula (4).

The developed methods of signal transformation allow selecting the necessary components from the input signals. After the necessary components are selected, the signal is averaged.

With the use of a band-pass filter, signals are cleared of low-frequency and high-frequency components, which have low informativeness in the original signals. Further averaging of the signal allows to reduce the influence of random amplitude and noise components of the signal, as well as to reduce its dimension.

This allows the use of processed signals in NN models more efficiently than the original signals. In practice, this will increase the speed of predictive models.

After the transformation of the original input data, a predictive model can be synthesized based on them.

In most HUMS as the predictive model used a feedforward NN [3-4]. These models demonstrate their per- 
formance for short-term forecasting, but as the time window between the input data and the target value of the forecast increases, the quality of the models decreases.

Models of RNN have connections between elements that create a directed sequence. This makes it possible to process successive series of events in time. Unlike multilayer perceptrons, RNN can use their internal memory to process sequences of arbitrary length.

At the moment, there are a large number of models of $\mathrm{RNN}$ and new architectures are being developed to solve various problems. In [14] analyzes the main models of RNN to solve the problem of long-term forecasting of the state of the helicopter transmission.

A four - layer recurrent neuron network with an input layer, two hidden layers with GRU-cell (Fig. 1) and an output layer with one linear neuron was chosen as a neural network model. GRU [15] is a simplified model of a well - known LSTM cell with significantly fewer parameters. Through this, learning GRU is easier than LSTM, so it is gaining popularity in many real-world tasks.

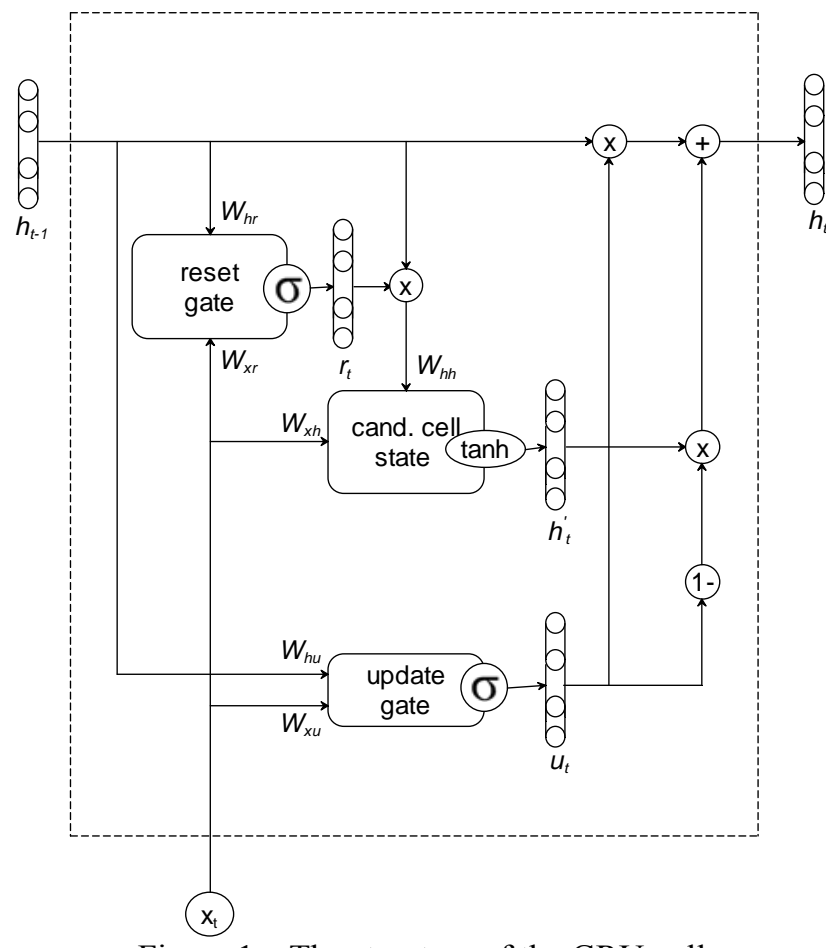

Figure 1 - The structure of the GRU-cell

At the input of the GRU-cell receives a vector $x$, which contains the current values of the signals. The output of the cell is calculated by the following formulas (6)-(9):

$$
\begin{gathered}
u_{t}=\sigma\left(W_{x u} x_{t}+W_{h u} h_{t-1}+b_{u}\right), \\
r_{t}=\sigma\left(W_{x r} x_{t}+W_{h r} h_{t-1}+b_{r}\right), \\
h_{t}^{\prime}=\tanh \left(W_{x h^{\prime}} x_{t}+W_{h h^{\prime}}\left(r_{t} \otimes h_{t-1}\right)\right), \\
h_{t}=\left(1-u_{t}\right) \otimes h_{t}^{\prime}+u_{t} \otimes h_{t-1},
\end{gathered}
$$

\section{EXPERIMENTS}

To study the proposed methods of signal transformation, they were implemented in software using WinPOS data processing procedures [16]. The NN model was implemented in Python using the PyTorch library [17].

During the experiment, from 15 original input signals, 22 artificial (calculated) signals were isolated and obtained using the proposed methods, which show the state of such transmission elements, such as: the first tooth of the main gear, rotor blade, tail shaft, the first tooth of the intermediate gearbox, the first tooth of the tail gearbox, tail rotor blade, tail rotor. Information about transformed

\begin{tabular}{|c|c|c|c|}
\hline \multirow{2}{*}{$\begin{array}{c}\text { Input } \\
\text { measureme } \\
\text { nt } \\
\text { location }\end{array}$} & \multirow{2}{*}{$\begin{array}{l}\text { Direction of } \\
\text { measurement }\end{array}$} & \multicolumn{2}{|c|}{$\begin{array}{l}\text { The signal obtained by the } \\
\text { proposed methods }\end{array}$} \\
\hline & & $\begin{array}{c}\text { Name of the } \\
\text { transmission } \\
\text { element }\end{array}$ & $\begin{array}{l}\text { Controlled } \\
\text { parameter }\end{array}$ \\
\hline \multirow{3}{*}{$\begin{array}{c}\text { Rotor shaft } \\
\text { cover }\end{array}$} & \multirow[t]{2}{*}{ Vertical } & $\begin{array}{l}\text { First gear drive } \\
\text { of the main } \\
\text { gearbox }\end{array}$ & $\begin{array}{l}\text { Vibration } \\
\text { overload }\end{array}$ \\
\hline & & \multirow{4}{*}{ Rotor blade } & \multirow{4}{*}{$\begin{array}{l}\text { Vibration } \\
\text { speed }\end{array}$} \\
\hline & Axial & & \\
\hline \multirow{2}{*}{$\begin{array}{l}\text { Coupling } \\
\text { flange of } \\
\text { the upper } \\
\text { and lower } \\
\text { part of the } \\
\text { gearbox }\end{array}$} & Vertical & & \\
\hline & Axial & & \\
\hline \multirow{3}{*}{$\begin{array}{c}\text { Drive } \\
\text { flange of } \\
\text { main rotor }\end{array}$} & Vertical & \multirow{6}{*}{ Tail shaft } & \multirow{6}{*}{$\begin{array}{c}\text { Vibration } \\
\text { speed }\end{array}$} \\
\hline & Horizontal & & \\
\hline & Axial & & \\
\hline \multirow{6}{*}{$\begin{array}{c}\text { Intermediat } \\
\text { e gearbox }\end{array}$} & Vertical & & \\
\hline & Horizontal & & \\
\hline & Axial & & \\
\hline & Vertical & \multirow{3}{*}{$\begin{array}{c}\text { First gear drive } \\
\text { of the } \\
\text { intermediate } \\
\text { gearbox }\end{array}$} & \multirow{3}{*}{$\begin{array}{l}\text { Vibration } \\
\text { overload }\end{array}$} \\
\hline & Horizontal & & \\
\hline & Axial & & \\
\hline \multirow{9}{*}{$\begin{array}{c}\text { Tail } \\
\text { gearbox }\end{array}$} & Vertical & \multirow{3}{*}{$\begin{array}{c}\text { First gear drive } \\
\text { of the tail } \\
\text { gearbox }\end{array}$} & \multirow{3}{*}{$\begin{array}{l}\text { Vibration } \\
\text { overload }\end{array}$} \\
\hline & Horizontal & & \\
\hline & Axial & & \\
\hline & Vertical & \multirow{3}{*}{ Tail rotor blade } & \multirow{3}{*}{$\begin{array}{l}\text { Vibration } \\
\text { speed }\end{array}$} \\
\hline & Horizontal & & \\
\hline & Axial & & \\
\hline & Vertical & \multirow{3}{*}{ Tail rotor } & \multirow{3}{*}{$\begin{array}{l}\text { Vibration } \\
\text { speed }\end{array}$} \\
\hline & Horizontal & & \\
\hline & Axial & & \\
\hline
\end{tabular}
signals is given in the Table 1 .

Table 1 - Information about the signals obtained by the proposed methods 
For recursive filtering in the proposed methods of signal conversion, a filter of 4-th order with the value of ripple factor $\varepsilon=0,3 \mathrm{~dB}$ was used. To integrate the signal by the method of RC-circuit, the number of averaging points is $N=800$. The signals were averaged over time $\tau=1 \mathrm{~s}$.

Four-layer RNN with GRU-cells were used in the experiments. It had 30 neurons in the first hidden layer and 15 neurons in the second. It was trained using the RMSprop method with learning rate 0.01 , one train batch contained 40 values [18].

Experiments were conducted during which the historical information on the progress of the 18 cycles of transmission tests (cycle duration $t=150 \mathrm{~s}$ ) was used as a training sample. The input signals were transformed by the proposed methods into signals characterizing the state of individual transmission elements.

The purpose of building a predictive model was to obtain a forecast of the state of the transmission element on the next test cycle based on a set of values of time steps (time window) on the current cycle. The size of the sliding time window equal to 3 was used in the experiments.

Data about signals of the first 14 cycles were used as training data. Data about the signals of the last 4 cycles were used as test data.

\section{RESULTS}

The frequency band was determined separately for each transmission element, according to its physical parameters. For example, for signal processing by the rotor blade parameter, the filter bandwidth of $1000-2750 \mathrm{~Hz}$ was used (Fig. 2).


Figure 2 - The example of using the proposed methods for processing the signal from the rotor shaft cover (vertical direction of measurement): $a$ - original signal; $b$ - processed signal
For signal processing by the tail rotor blade parameter, the filter bandwidth of $20-45 \mathrm{~Hz}$ was used. The results of the proposed methods are shown in Fig. 3.

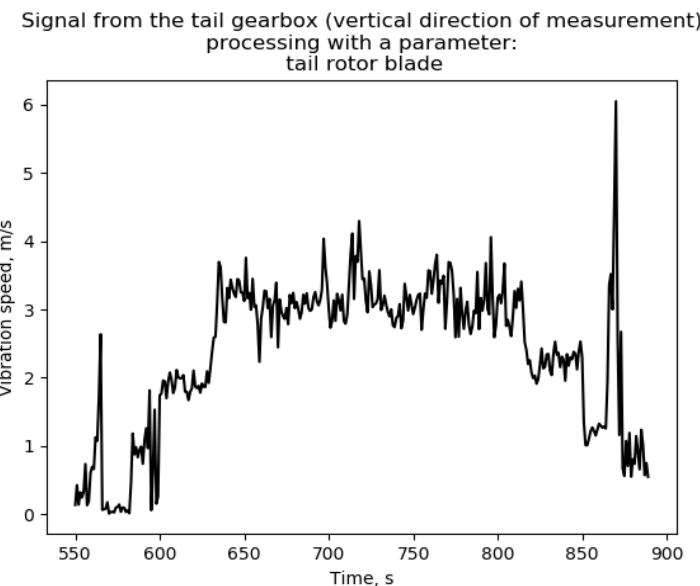

Signal from the tail gearbox (horizontal direction of measurement) processing with a parameter:

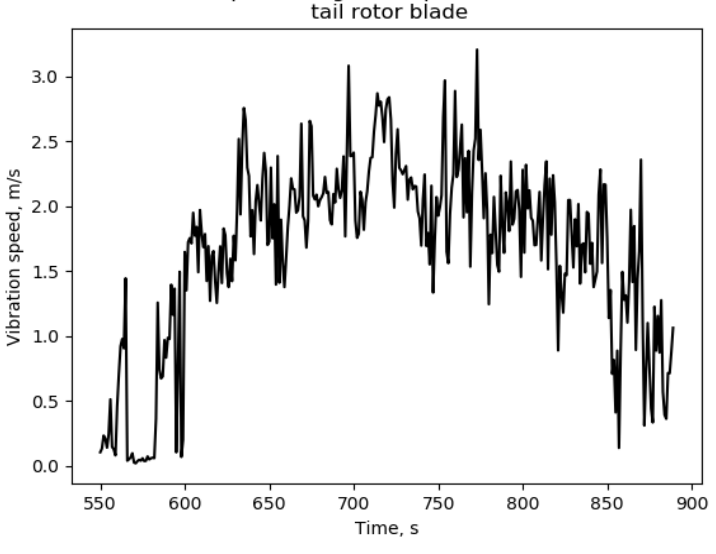

b

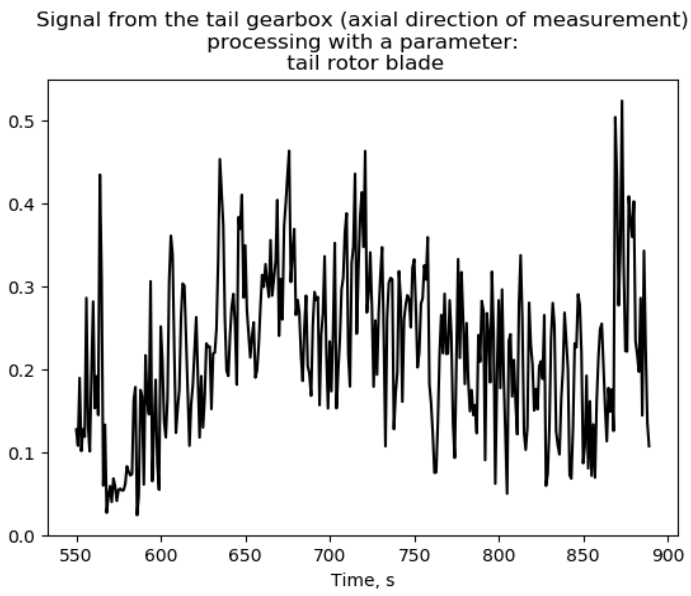

C

Figure 3 - The results of using the proposed methods the signal from the tail gearbox processing with a parameter: tail rotor blade: $\mathrm{a}$ - vertical direction of measurement; $\mathrm{b}$ - horizontal direction of measurement; $\mathrm{c}$ - axial direction of measurement 
Predictive models were synthesized on the basis of the processed signals. As output signals, during the experiment, all received signals were used alternately.

To assess the quality of the forecast, we used the mean squared error of the forecast of the signal by the formula (10):

$$
E=\frac{1}{N} \sum_{s=1}^{S}\left(y^{s}-F\left(\omega, x^{s}\right)\right)^{2}
$$

Predictive models were synthesized on the basis of the processed signals. As output signals, during the experiment, all received signals were used alternately.

Predictive models were synthesized on the basis of the processed signals. As output signals, during the experiment, all received signals were used alternately.

For example, the prediction error for the signal received on the intermediate gearbox (axial direction of measurement) and processed with a parameter: first gear drive of the intermediate gearbox is 0.0167 , which corresponds to $13.45 \%$. According to expert estimates, this error is acceptable for the problem of predicting the transmission of the helicopter.



Figure 4 - The example of prediction signal values received on the intermediate gearbox (axial direction of measurement) and processed with a parameter: first gear drive of the intermediate gearbox

The fragment of the results of conducted experiments for this and other examples is presented in the Table 2.

Table 2 - Information about the signals obtained by the proposed methods

\begin{tabular}{|c|c|c|}
\hline $\begin{array}{c}\text { Input } \\
\text { measurement } \\
\text { location }\end{array}$ & $\begin{array}{c}\text { Direction of } \\
\text { measurement }\end{array}$ & $\begin{array}{c}\text { Forecast error } \\
\text { (percent), \% }\end{array}$ \\
\hline \hline Rotor shaft cover & Vertical & 13.20 \\
\hline \multirow{2}{*}{ Tail gearbox } & Vertical & 9.58 \\
\cline { 2 - 3 } & Horizontal & 12.95 \\
\hline $\begin{array}{c}\text { Intermediate } \\
\text { gearbox }\end{array}$ & Axial & 15.64 \\
\hline
\end{tabular}

(C) Lymariev I. O., Subbotin S. A., Oliinyk A. A., Drokin I. V., 2018 DOI 10.15588/1607-3274-2018-4-11

\section{DISCUSSION}

The use of the proposed methods made it possible to obtain a set of signals for effective prediction of the state of the object of diagnosis. The general condition of the diagnostic object is characterized by a multivariative time series. The most flexible tool for forecasting such series is $\mathrm{NN}$ forecasting models. The results shown in table 2 demonstrate that the model built on the basis of the received signals provides the necessary forecasting accuracy.

The advantage of using processed signals is that their dimension is many times smaller than the dimension of the input signals. Also, these signals are more informative for the expert and don't require further processing after receiving the forecast.

The disadvantages of the proposed methods are that in order to obtain high prediction accuracy it is necessary to have a large set of input signals. However, the modern process of diagnosis often has a large amount of historical information in the form of signals with a high sampling rate.

Also, the developed methods can be basic for the development of more specialized methods for predicting individual characteristics of the diagnosis signal. For example, to predict the sharp vibration jumps about the diagnosis of technical objects, which often leads to the failure of the object.

The results of the experiments shown in Fig. 4 and table 2 demonstrate the efficiency and flexibility of the developed methods. Based on this, the proposed methods can be effectively used in practice to predict the state of the object of diagnosis.

\section{CONCLUSIONS}

The urgent problem of reducing the dimension of diagnosis signals for the synthesis of data-driven neural network diagnosis models is considered.

The scientific novelty of obtained results is the methods of signal transformation based on signal processing are proposed. They are based on the methods of signal processing, solve the problem of selecting the desired components of the signal, and reduce its dimension. The developed methods can significantly reduce the dimension of the input signals, without reducing their informativeness. This allows to increase the speed of synthesis of NN models based on transformed signals.

The practical significance of obtained results is that the software realizing and used to solve practical regression problems. The experiments have confirmed the efficiency of the developed proposed software and allow us to recommend it for use in practice for the problems of synthesis of models based on precedents, which are presented as signals.

Prospects for further research are parallelization of calculations and optimization of software implementation of the proposed methods, also as experimental study of the proposed methods with different internal parameters of the settings on the larger complex of practical problems having different nature and dimension. 


\section{ACKNOWLEDGEMENTS}

The work was performed with partial support of international project "Internet of Things: Emerging Curriculum for Industry and Human Applications" (Reference number 573818-EPP-1-2016-1-UK-EPPKA2-CBHE-JP) by the Erasmus ${ }^{+}$programme of the European Union.

\section{REFERENCES}

1. Shin Y. C., Xu C. Intelligent systems: modeling, optimization, and control. Boca Raton, CRC Press, 2009, 456 p.

2. Bishop C. M. Pattern recognition and machine learning. New York, Springer, 2006, 738 p.

3. Giurgiutiu V., Cuc A., Goodman P. Review of vibration-based helicopters health and usage monitoring methods, 55th Meeting of the Society for Machinery Failure Prevention Technology, Virginia Beach, 2-5 April 2001 : proceedings. Virginia Beach, 2001, pp. 34-44.

4. Kazlas P. T., Monsen P. T., LeBlanc M. J. Neural networkbased helicopter gearbox health monitoring system, Neural Networks for Signal Processing, Proceedings of the IEEE-SP Workshop, 6-9 September 1993, proceedings, 1993, pp. 431440.

5. Dempsey P., Lewicki D., Le D. Investigation of current methods to identify helicopter gear health, 7 IEEE Aerospace Conference, 3-10 March 2007, proceedings. Montana, 2007, pp. 81-87.

6. Subbotin S. A., Oliinyk A.A. The dimensionality reduction methods based on computational intelligence in problems of object classification and diagnosis, Advances in Intelligent Systems and Computing, 2017, Vol. 543, pp. 11-19.
7. Jensen R., Shen Q. Computational intelligence and feature selection: rough and fuzzy approaches. Hoboken, John Wiley \& Sons, 2008, $339 \mathrm{p}$

8. Lee J. A. Nonlinear dimensionality reduction. New York, Springer, 2007, $308 \mathrm{p}$.

9. Guyon I., Elisseeff A. An introduction to variable and feature selection, Journal of machine learning research, 2003, No. 3, pp. $1157-1182$.

10. Ukil A. Intelligent systems and signal processing in power engineering. Berlin, Springer, 2007, $378 \mathrm{p}$

11. Feldman M. Hilbert Transform Applications in Mechanical Vibration. Chichester, John Wiley, 2011, $320 \mathrm{p}$

12. Hagen J. B. Radio-Frequency Electronics: Circuits and Applications. New York, Cambridge University Press, 2009, 438 p.

13. Venkata R. Rama S., Manmadha R. Pulse and Digital Circuits. New Dehli, Pearson, 2010, 709 p.

14. Limarev I. O. Dovgoterminove prognozuvannya stany transmisii vertoletu na osnovi rekurentnih neyronnih merezh, Radioelektronika i molod v XXI st. : Mizhnarodniy molodizhniy forum. Harkiv, 2018, Vol. 5, pp. 223-224 (in Ukrainian).

15. Cho K. et al. On the Properties of Neural Machine Translation [Electronic resource]. Access mode: http://arxiv.org/abs/1409.1259.

16. WinPOS Documentation [Electronic resource]. Access mode: $\mathrm{http} / / / \mathrm{nppmera} \cdot \mathrm{ru} /$ documentation/.

17. PyTorch Tutorials [Electronic resource]. Access mode: https://pytorch.org/tutorials/.

18. Goodfellow I., Bengio Y., Courville A. Deep Learning [Electronic resource]. Access mode http://www.deeplearningbook.org.

Received 22.08.2018 Accepted 10.09.2018.

УДК 004.93

\section{МЕТОДИ ПЕРЕТВОРЕННЯ СИГНАЛІВ ВЕЛИКОЇ РОЗМІРНОСТІ ДЛЯ ДІАГНОСТУВАННЯ У НЕЙРОМЕРЕЖЕВИХ} МОДЕЛЯХ

Лимарєв І. О.- студент кафедри програмних засобів Запорізького національного технічного університету, Запоріжжя, Україна.

Субботін С. О. - д-р техн. наук, професор, завідувач кафедри програмних засобів Запорізького національного технічного університету, Запоріжжя, Україна.

Олійник А. О. - канд. техн. наук, доцент, доцент кафедри програмних засобів Запорізького національного технічного університету, Запоріжжя, Україна.

Дрокін І. В. - начальник відділу досліджень УГК «Мотор Січ», Запоріжжя, Україна.

\section{АНОТАЦІЯ}

Актуальність. Розглянуто задачу зменшення розмірності сигналів діагностування для їх використання у нейромережевих моделях. Об'єктом дослідження $є$ процес перетворення вхідних сигналів діагностування для їх подальшого використання при побудови прогнозуючих моделей. Мета роботи - створення методів для перетворення сигналів діагностування у результаті використання яких будуть отримані нові сигнали, які у свою чергу будуть використані при побудові нейромережевих прогнозуючих моделей та дозволять значно скоротити час синтезу моделі за рахунок скорочення їх розмірності та виділення необхідних компонент, що характеризують стан окремих елементів об'єкту діагностування.

Метод. Запропоновано методи, що дозволяють одночасно скоротити розмірність вхідних сигналів діагностування та виділи з них компоненти, що характеризують стан окремих елементів об'єкту діагностування на основі експертних знань про процес діагностування. Розроблені методи базуються на основі методів цифрової обробки сигналів. Відповідно до експертних знань про об'єкт та процес діагностування обираються необхідні процедури перетворення сигналів та їх параметри. Відповідно вимогам до бажаної точності та детальності отримуваного прогнозу обирається оптимальний ступень усереднення сигналу, який напряму впливає на швидкість побудови прогнозуючої моделі. Запропоновані методи можуть бути використані для перетворення сигналів діагностування різноманітних діагностичних процесів де $\epsilon$ потреба у побудові нейромережевих прогнозуючих моделей на основі сигналів великої розмірності. Були проведені дослідження розроблених методів для перетворення сигналів діагностування отриманих на складному об'єкті технічної діагностики, а саме на трансмісії гелікоптера. На основі отриманих сигналів було синтезовано нейромережеву модель, навчання якої потребує набагато менших обчислювальних ресурсів, при цьому точність прогнозування залишається оптимальною.

Результати. Розроблені методи реалізовані програмно і досліджені при вирішенні задачі прогнозування майбутнього стану трансмісії гелікоптера під час процесу діагностування.

Висновки. Проведені експерименти підтвердили ефективність розроблених методів і дозволяють рекомендувати його для використання на практиці при вирішенні задач діагностування. Перспективи подальших досліджень можуть полягати в пошуку кращих параметрів розроблених методів, оптимізації їх програмних реалізацій, а також експериментальному дослідженні запропонованих методів на більшому комплексі практичних задач діагностування складних об'єктів різної природи за їх діагностичними сигналами.

КЛЮЧОВІ СЛОВА: цифрова обробка сигналів, нейрона мережа, екземпляр, ознака, зменшення розмірності. 


\section{МЕТОДЫ ПРЕОБРАЗОВАНИЯ СИГНАЛОВ БОЛЬШОЙ РАЗМЕРНОСТИ ДЛЯ ДИАГНОСТИРОВАНИЯ В} НЕЙРОСЕТЕВЫХ МОДЕЛЯХ

Лимарев И. О. - студент кафедры программных средств Запорожского национального технического университета, Запорожье, Украина.

Субботин С. А. - д-р техн. наук, профессор, заведующий кафедрой программных средств Запорожского национального технического университета, Запорожье, Украина.

Олейник А. А. - канд. техн. наук, доцент, доцент кафедры программных средств Запорожского национального технического университета, Запорожье, Украина.

Дрокин И. В. - начальник отдела исследований УГК «Мотор Сич», Запорожье, Украина.

\section{АННОТАЦИЯ}

Актуальность. Рассмотрена задача уменьшения размерности сигналов диагностирования для их использования в нейросетевых моделях. Объектом исследования являлся процесс преобразования входных сигналов диагностирования для их последующего использования при построении прогнозирующих моделей. Цель работы - создание методов для преобразования сигналов диагностирования в результате применения которых будут получены новые сигналы, которые в свою очередь будут использованы при построении нейросетевых прогнозирующих моделей и позволят значительно сократить время синтеза модели за счет сокращения их размерности и выделения необходимых компонент, которые характеризуют состояние отдельных элементов объекта диагностирования.

Метод. Предложены методы, которые позволяют одновременно сократить размерность входных сигналов диагностирования и выделить из них компоненты, которые характеризуют состояние отдельных элементов объекта диагностирования на основании экспертных знаний про процесс диагностирования. Разработанные методы базируются на основе методов цифровой обработки сигналов. Исходя из экспертных знаний о объекте и процессе диагностирования выбираются необходимые процедуры преобразования сигналов и их параметры. В соответствии требования к желаемой точности и детальности прогноза выбирается оптимальная степень усреднения сигнала, которая напрямую влияет на скорость построения прогнозирующей модели. Предложенные методы могут быть использованы при преобразовании сигналов диагностирования разнообразных диагностирующих процессов где есть необходимость в построении нейросетевых прогнозирующих моделей на основе сигналов большой размерности. Были проведены исследования разработанных методов для преобразования сигналов диагностирования полученных на сложном объекте технического диагностирования, а именно на трансмиссии вертолета. На основе полученных сигналов было синтезировано нейросетевую модель, обучение которой требует намного меньших вычислительных ресурсов, при этом точность прогнозирования остается оптимальной

Результаты. Разработанные методы реализованы программно и исследованы при решении задачи прогнозирования будущего состояния трансмиссии вертолета во время процесса диагностирования.

Выводы. Проведенные эксперименты подтвердили эффективность разработанных методов и позволяют рекомендовать их для использования на практике при решении задач диагностирования. Перспективы дальнейших исследования могут состоять в поиске лучших параметров разработанных методов, оптимизации их программных реализаций, а также экспериментальному исследованию предложенных методов на большем комплексе практических задач диагностирования сложных объектов разной природы по их диагностическим сигналам.

КЛЮЧЕВЫЕ СЛОВА: цифровая обработка сигналов, нейронная сеть, экземпляр, признак, уменьшение размерности.

\section{ЛІТЕРАТУРА / ЛИТЕРАТУРА}

1. Shin Y. C. Intelligent systems: modeling, optimization, and control / Y. C. Shin, C. Xu. - Boca Raton : CRC Press, 2009. $456 \mathrm{p}$.

2. Bishop C. M. Pattern recognition and machine learning / C. M Bishop. - New York : Springer, 2006. - 738 p.

3. Giurgiutiu V. Review of vibration-based helicopters health and usage monitoring methods / V. Giurgiutiu, A. Cuc, P. Goodman // 55th Meeting of the Society for Machinery Failure Prevention Technology, Virginia Beach, 2-5 April 2001 : proceedings. Virginia Beach, 2001. - P. 34-44.

4. Kazlas P. T. Neural network-based helicopter gearbox health monitoring system / P. T. Kazlas, P. T. Monsen, M. J. LeBlanc // Neural Networks for Signal Processing, Proceedings of the IEEE-SP Workshop, 6-9 September 1993 : proceedings, 1993. - P. 431-440.

5. Dempsey P. Investigation of current methods to identify helicopter gear health / P. Dempsey, D. Lewicki, D. Le // 7 IEEE Aerospace Conference, 3-10 March 2007 : proceedings. - Montana, 2007. - P. 81-87.

6. Subbotin S. A The dimensionality reduction methods based on computational intelligence in problems of object classification and diagnosis / S. A. Subbotin, A. A. Oliinyk // Advances in Intelligent Systems and Computing. - 2017. - Vol. 543. - P. 1119 .

7. Jensen R. Computational intelligence and feature selection: rough and fuzzy approaches / R. Jensen, Q. Shen. - Hoboken : John Wiley \& Sons, 2008. - 339 p.
8. Lee J. A. Nonlinear dimensionality reduction / A. J. Lee. - New York : Springer, 2007. $-308 \mathrm{p}$.

9. Guyon I. An introduction to variable and feature selection / I. Guyon, A. Elisseeff // Journal of machine learning research. 2003. - No. 3. - P. 1157-1182.

10. Ukil A. Intelligent systems and signal processing in power engineering / A. Ukil. - Berlin : Springer, 2007. - 378 p.

11. Feldman M. Hilbert Transform Applications in Mechanical Vibration / M. Feldman. - Chichester : John Wiley, 2011. - 320 $\mathrm{p}$

12. Hagen J. B. Radio-Frequency Electronics: Circuits and Applications / J. B. Hagen. - New York : Cambridge University Press, 2009. $-438 \mathrm{p}$.

13. Venkata R. Pulse and Digital Circuits / R. Venkata, S. Rama, R. Manmadha. - New Dehli : Pearson, 2010. - 709 p.

14. Limarev I. O. Dovgoterminove prognozuvannya stany transmisii vertoletu na osnovi rekurentnih neyronnih merezh / I. O. Limarev // Radioelektronika i molod v XXI st. : Mizhnarodniy molodizhniy forum, Harkiv, 2018. - Vol. 5. - P. 223-224 (in Ukrainian)

15. Cho K. On the Properties of Neural Machine Translation [Electronic resource] / K. Cho et al. - Access mode: http://arxiv.org/abs/1409.1259.

16. WinPOS Documentation [Electronic resource]. - Access mode: http://nppmera.ru/documentation/

17. PyTorch Tutorials [Electronic resource]. - Access mode: https://pytorch.org/tutorials/.

18. Goodfellow I. Deep Learning [Electronic resource] / I. Goodfellow, Y. Bengio, A. Courville. - Access mode: http://www.deeplearningbook.org. 